\title{
Creation of an international registry to support discovery in schwannomatosis
}

DOI:

10.1002/ajmg.a.38024

\section{Document Version}

Accepted author manuscript

Link to publication record in Manchester Research Explorer

\section{Citation for published version (APA):}

Ostrow, K. L., Bergner, A. L., Blakeley, J., Evans, G., Ferner, R., Friedman, J. M., Harris, G. J., Jordan, J. T., Korf, B., Langmead, S., Leschziner, G., Mautner, V., Merker, V. L., Papi, L., Plotkin, S. R., Slopis, J. M., Smith, M. J., Stemmer-Rachamimov, A., Yohay, K., \& Belzberg, A. J. (2016). Creation of an international registry to support discovery in schwannomatosis. American Journal of Medical Genetics. Part A.

https://doi.org/10.1002/ajmg.a.38024

Published in:

American Journal of Medical Genetics. Part A

\section{Citing this paper}

Please note that where the full-text provided on Manchester Research Explorer is the Author Accepted Manuscript or Proof version this may differ from the final Published version. If citing, it is advised that you check and use the publisher's definitive version.

\section{General rights}

Copyright and moral rights for the publications made accessible in the Research Explorer are retained by the authors and/or other copyright owners and it is a condition of accessing publications that users recognise and abide by the legal requirements associated with these rights.

\section{Takedown policy}

If you believe that this document breaches copyright please refer to the University of Manchester's Takedown Procedures [http://man.ac.uk/04Y6Bo] or contact uml.scholarlycommunications@manchester.ac.uk providing relevant details, so we can investigate your claim.

\section{OPEN ACCESS}




\section{Creation of an International Registry to Support Discovery in}

Schwannomatosis

Ostrow KL1*, Bergner AL1*, Blakeley J1, Evans DG2, Ferner R3, Friedman, JM4, Harris GJ5, Jordan, JT5 ,Korf B6, Langmead $\mathrm{S}_{1}$, Leschziner $\mathrm{G}_{3}$, Mautner $\mathrm{V}_{7}$, Merker $\mathrm{V}_{5}$, Papi L8, Plotkin SR5, Slopis JM9, Smith $\mathrm{MJ}_{2}$, Stemmer-Rachamimov A5, Yohay K10, Belzberg $\mathrm{AJ}_{1}$

1. Johns Hopkins University, 2. University of Manchester, 3.Guy's Hospital in London, 4. University of British Columbia, 5. Massachusetts General Hospital, 6. University of Alabama at Birmingham, 7. University of Hamburg, 8. University of Florence, 9. MD Anderson Cancer Center, 10. Weill Cornell Medical College

*authors contributed equally to this work

Correspondence:

Dr. Allan Belzberg

600 N. Wolfe Street

Meyer Building 5-181

Baltimore, MD 21287

Phone: 410-955-5810

Fax: 410-614-9830

Abelzbe1@jhmi.edu 


\begin{abstract}
Schwannomatosis is a tumor suppressor syndrome that causes multiple tumors along peripheral nerves. Formal diagnostic criteria were first published in 2005. Variability in clinical presentation and a relative lack of awareness of the syndrome have contributed to difficulty recognizing affected individuals and accurately describing the natural history of the disorder. Many critical questions such as the mutations underlying schwannomatosis, genotype phenotype correlations, inheritance patterns, pathologic diagnosis of schwannomatosis associated schwannomas, tumor burden in schwannomatosis, the incidence of malignancy and the effectiveness of current or new treatments remain unanswered. A well-curated registry of schwannomatosis patients is needed to facilitate research in field. An international consortium of clinicians and scientists across multiple disciplines with expertise in schwannomatosis was established and charged with the task of designing and populating a schwannomatosis patient registry. The International Schwannomatosis Registry (ISR) was built around key data points that allow confirmation of the diagnosis and identification of potential research subjects to advance research to further the knowledge base for schwannomatosis. A registry with 389 participants enrolled to date has been established. Twenty-three additional subjects are pending review. A formal process has been established for scientific investigators to propose research projects, identify eligible subjects, and seek collaborators from ISR sites. Research collaborations have been created using the information collected by the registry and are currently being conducted. The ISR is a platform from which multiple research endeavors can be launched, facilitating connections between affected individuals interested in participating in research and researchers actively investigating a variety of aspects of schwannomatosis.
\end{abstract}


Keywords: Schwannomatosis; Schwannoma; registry; SMARCB1; LZTR1

\section{Abbreviations:}

SWN: schwannomatosis

ISR: International schwannomatosis registry

NF2: neurofibromatosis type 2

$\mathrm{FH}$ : family history 


\section{INTRODUCTION}

Schwannomatosis is a syndrome characterized by the presence of multiple schwannomas - nerve sheath tumors composed of Schwann cells. These tumors are nearly always benign but can cause significant morbidity in the form of neuropathic pain, neurologic disability, or regional organ compression [MacCollin et al 2003; MacCollin et al 2005].

It is a rare disorder with incidence estimates varying from $1 / 70,000$ to $1 / 40,000$ [Koontz 2013]. Formal diagnostic criteria were established ten years ago [MacCollin et al 2005; Baser 2006] (Table I). Individuals with schwannomatosis are known to medical centers around the world, but most centers provide care for only a small number of patients. This reality has contributed to the natural history of schwannomatosis being poorly understood and based on small case series from individual centers [Li et al 2016; Merker et al 2012; Gonzalvo et al 2011; Huang et al 2004]. Additional complexity comes from the genetic and phenotypic variability of schwannomatosis. Together, these factors impair identification of people affected by schwannomatosis and limits enrollment for clinical and translational studies.

In order to facilitate advances in clinical, translational, and basic science discoveries that could serve people living with schwannomatosis, affected individuals who wish to participate in research must be identified and connected with teams performing research. This daunting task can be simplified by creating an international patient registry that contains well-curated clinical data.

The primary goals of this Children's Tumor Foundation (CTF) registry are: (1) worldwide participation of all interested medical centers and potential research subjects; (2) reasonable cost; (3) quality control of the data entered; and (4) identification of sustainable funding for the Registry.

\section{METHODS \\ Design}

Stakeholders. The Johns Hopkins Comprehensive Neurofibromatosis Center (JHCNC) was contracted to develop and operate the registry using a web-based model. The first phase of the project involved identifying and aligning experts in the field of schwannomatosis to build consensus about the core, critical data points to collect within the registry. Fifteen investigators from eleven institutions in eight countries participated in the initial planning meeting to decide on the structure and content of the registry. The group concluded that the strengths of an online registry were:

1) Ease of access at participating sites around the world;

2) Ease with which affected individuals appropriate for particular research studies could be identified;

3) Ability to amass a larger volume of individuals with schwannomatosis than currently existed at any one center.

Concerns regarding a registry model were also discussed and included:

1) Entry of inaccurate data thereby rendering the registry useless

2) Time required to enter patient data at each site

3) Who "owns" the data entered into the registry 
As the structure of the registry was designed, all of these concerns were considered and addressed so as to minimize their potential negative impact on the project.

Infrastructure. The infrastructure for the International Schwannomatosis Registry (ISR) was designed with both an operations unit and a governing unit. JHCNFC was identified to take the lead in coordinating the operation of the project. At this site, the principal investigator (PI) and project coordinator developed the functional aspects of the registry, including initial Internal Review Board (IRB)/Ethics Committee approval. Guidance and written materials were provided to all sites wishing to participate in order to facilitate obtaining local IRB/Ethics Committee approvals and consistent enrollment of subjects and data entry. A Steering Committee was established to provide scientific oversight for the ISR. The Steering Committee consists of three voting members who were elected by the members of the initial group of experts. Non-voting members of the Steering Committee are the $\mathrm{Pl}$, project coordinator, a representative from the schwannomatosis lay community, and a representative from the funding agency. By-laws for the Steering Committee were proposed by the $\mathrm{PI} /$ project coordinator and then edited and ultimately ratified by the initial group of experts.

Registry structure and content. The structure and content of the registry were designed to contain limited, de-identified information that provides a general overview of the clinical features of individuals enrolled. This design addresses the anticipated issues of transferring patient data out of an institution into a registry through internet web-based mechanism, as well as the varied IRB/Ethics Committee regulations that were expected due to the international nature of the project.

Additionally, at the initial gathering of experts, key questions of interest in the field of schwannomatosis were identified (Table II). It was agreed that approximately twenty data points would be designed and collected for each subject that enrolled (Table III). Querying the registry would then identify subjects suitable for the various research projects prompting the investigator to collaborate with investigators at each site who entered the subjects into the registry. There are sufficient data to allow collaboration across centers yet maintain the independence of individual centers and investigators.

Registry platform and management. ISR data are collected and managed using REDCap, a secure, web-based application designed to support data capture for clinical research studies [Harris et al 2009]. We also established a website to provide more information about the ISR and assist with the accrual of interested subjects (www.schwannomatosis.com).

Enrollment. Each site identifies their own potential subjects, obtains informed consent and enters their subjects' data into the ISR. Additionally, a mechanism called "Iong distance enrollment" allows for the inclusion of subjects with schwannomatosis who are not associated with any of the participating sites but who would like to be enrolled into the ISR. Informed consent is obtained via telephone, and potential subjects submit their medical records, including MRI scans and genetic testing reports, to the coordinating site to verify eligibility. Each file is reviewed by a clinician expert in schwannomatosis at the coordinating site to determine whether diagnostic criteria for schwannomatosis are met. If criteria are met, the patient is enrolled in the registry. 
Data availability and use. The ISR serves as a platform by which people living with schwannomatosis and interested in participating in research can be connected with researchers in this field. Interested researchers submit a letter of intent (LOI) that includes: 1) a summary of the research project; 2 ) a description of the eligibility criteria; 3 ) specific aims; 4) a brief description of research design; 5) the significance of the proposed project; and a biographical sketch of study principal investigator. The Steering Committee reviews the study to ensure that it is feasible and that the data sought are appropriate. If the LOI is approved, the ISR operations unit queries the registry and provides the investigator with the contact information for all participating institutions that have entered subjects who meet the eligibility requirements. The investigator then reaches out to the $\mathrm{PI}$ at each individual site and they establish a collaboration directly. If a site chooses to participate, the site PI completes all appropriate regulatory materials at their site and contacts eligible subjects to offer participation in the study.

\section{RESULTS}

Ten sites from the United States, the United Kingdom, Germany, Italy, Canada, and Israel have enrolled a total of 385 subjects in the ISR. An additional 4 subjects have been enrolled through the long distance method, with 23 more pending medical records review. The median age at diagnosis is 30 years (range: $5-75$ ), with $50 \%$ of patients diagnosed in the third or fourth decades of life (Table IV). There are similar numbers of males and females enrolled in the ISR. Pain is a major symptom of schwannomatosis, with $75 \%$ of the subjects having experienced pain. $72 \%$ of patients presented for medical attention due to pain (either pain alone or along with a palpable mass, and/or neurological deficit). Of those who did not present with pain, $17 \%$ presented with a mass only, $4 \%$ with a neurological deficit as the only symptom, and $3 \%$ presenting with palpable mass and a neurological deficit. $1 \%$ of patients had no symptoms and were identified by incidental finding on imaging. The majority of subjects do not have a known family history of schwannomatosis. Genetic testing results for germline SMARCB1 mutations, and/or germline LZTR1 mutations or somatic mutations in NF2 in tumors have been collected for $34 \%$ of subjects. Of the patients tested, 53\% carried a germline mutation in SMARCB1. 47\% carried a germline mutation in LZTR1. 108 out of the 389 patients enrolled in the ISR have tissue banked and available for research. (Table V) To date, three LOIs have been reviewed and accepted, and recruitment of subjects identified using the ISR is underway.

\section{DISCUSSION}

This project has increased communication and collaboration within the schwannomatosis community and has facilitated connections among researchers studying schwannomatosis and affected individuals wanting to participate in research. The successful initiation of three collaborative research projects demonstrates the value of the ISR as a platform to accelerate research in the field of schwannomatosis. These multi-site studies would not have been possible without ISR, as they require more patients than are seen at a single center.

Evaluation of study design and relevance to the schwannomatosis community is effected through the process of Steering Committee review of LOIs. This model provides access to the key resource of subject data (clinical data, blood, tissue, imaging) that will allow many of the key questions regarding this disease (SMARCB1, LTZR1 gene effects, 
the influence of epigenetics, epidemiology, family history and disease penetration, cause of pain, pain prevention, malignancy risk, etc.) to be addressed by collaborators throughout the world. Thismodel ensures that there is worldwide, immediate access to basic data from almost 400 patients with schwannomatosis, but that no patient data are released without specific consent and the fulfillment of regional regulatory standards. Additionally, each investigator maintainsautonomy and can choose which research studies to participate in. The diagnostic criteria for schwannomatosis are evolving as researchers discover more about this disease (see Table I). The diagnostic criteria were first established in 2005 and revised in 2006 [MacCollin et al 2005; Baser et al 2006]. In 2011 a group of experts in schwannomatosis revisited and updated the diagnostic criteria to include germline mutations in the SMARCB1 gene [Plotkin et al 2013] In 2013, the ISR collaborators met to refine the diagnostic criteria of schwannomatosis for inclusion into the registry. Mutations in LZTR1 were added to the molecular diagnosis, and it was agreed that patients with unilateral vestibular schwannoma could be included if the patient was over 40 years of age. The participating sites will be periodically asked to review the latest criteria and perform a quality control check on their patients.

In conclusion, the International Schwannomatosis Registry serves as a core resource of quality controlled information for supporting high-quality, high-impact, multi-site research in schwannomatosis.

\section{ACKNOWLEDGEMENTS}

Many thanks to our collaborators on this project from Mayo Clinic, Tel-Aviv University, University of Manchester, Guy's Hospital in London, Massachusetts General Hospital, University of Indiana, University of Hamburg, University of British Columbia, House Research Institute, Academic Medical Center in Amsterdam, University of Alabama at Birmingham, University of Florence, Weill Cornell Medical College, The University of Central Florida, The Oregon Health and Science University and Johns Hopkins University. This work has been generously supported by a grant from the Children's Tumor Foundation. 


\section{References:}

Baser, M.E., Friedman, J.M. Evans, D.G., 2006. Increasing the specificity of diagnostic criteria for schwannomatosis. Neurology, 66(5), pp. 730-732.

Boyd, C., Smith, M.J., Kluwe, L., Balogh, A., Maccollin, M., Plotkin, S.R., 2008. Alterations in the SMARCB1 (INI 1) tumor suppressor gene in familial schwannomatosis. Clinical genetics, 74(4), pp. 358-366.

Gonzalvo, A., Fowler, A., Cook, R.J., Little, N.S., Wheeler, H., Mcdonald, K.L., Biggs, M.T., 2011. Schwannomatosis, sporadic schwannomatosis, and familial schwannomatosis: a surgical series with long-term follow-up. Clinical article. Journal of neurosurgery, 114(3), pp. 756-762.

Harris, P.A., Taylor, R., Thielke, R., Payne, J., Gonzalez, N., Conde, J.G., 2009. Research electronic data capture (REDCap)--a metadata-driven methodology and workflow process for providing translational research informatics support. Journal of Biomedical Informatics, 42(2), pp. 377-381.

Huang, J.H., Simon, S.L., Nagpal, S., Nelson, P.T., Zager, E.L., 2004. Management of patients with schwannomatosis: report of six cases and review of the literature. Surgical neurology, 62(4), pp. 353-61; discussion 361.

Hulsebos, T.J., Plomp, A.S., Wolterman, R.A., Robanus-Maandag, E.C., Baas, F., Wesseling, P., 2007. Germline mutation of INII/SMARCB1 in familial schwannomatosis. American Journal of Human Genetics, 80(4), pp. 805-810.

Hutter, S., Piro, R.M., Reuss, D.E., Hovestadt, V., Sahm, F., Farschtschi, S., Kehrer-Sawatzki, H., Wolf, S., Lichter, P., Von Deimling, A., Schuhmann, M.U., Pfister, S.M., Jones, D.T., Mautner, V.F., 2014. Whole exome sequencing reveals that the majority of schwannomatosis cases remain unexplained after excluding SMARCB1 and LZTR1 germline variants. Acta Neuropathologica, 128(3), pp. 449-452.

Koontz Na, Wiens Al, Agarwal A, Hingtgen Cm, Emerson Re, Mosier Km. 2013. Schwannomatosis: the overlooked neurofibromatosis? AJR Am J Roentgenol. 200(6):W646-53.

Li, P., Zhao, F., Zhang, J., Wang, Z., Wang, X., Wang, B., Yang, Z., Yang, J., Gao, Z., Liu, P., 2016. Clinical features of spinal schwannomas in 65 patients with schwannomatosis compared with 831 with solitary schwannomas and 102 with neurofibromatosis Type 2: a retrospective study at a single institution. Journal of neurosurgery.Spine, 24(1), pp. 145-154.

Maccollin, M., Chiocca, E.A., Evans, D.G., Friedman, J.M., Horvitz, R., Jaramillo, D., Lev, M., Mautner, V.F., Niimura, M., Plotkin, S.R., Sang, C.N., Stemmer-Rachamimov, A. Roach, E.S., 2005. Diagnostic criteria for schwannomatosis. Neurology, 64(11), pp. 1838-1845.

Maccollin, M., Willett, C., Heinrich, B., Jacoby, L.B., Acierno, J.S.,J r, Perry, A. and Louis, D.N., 2003. Familial schwannomatosis: exclusion of the NF2 locus as the germline event. Neurology, 60(12), pp. 1968-1974.

Maccollin, M., Woodfin, W., Kronn, D. Short, M.P., 1996. Schwannomatosis: a clinical and pathologic study. Neurology, 46(4), pp. 1072-1079.

Merker, V.L., Esparza, S., Smith, M.J., Stemmer-Rachamimov, A, Plotkin, S.R., 2012. Clinical features of schwannomatosis: a retrospective analysis of 87 patients. The oncologist, 17(10), pp. 1317-1322.

Piotrowski, A., Xie, J., Liu, Y.F., Poplawski, A.B., Gomes, A.R., Madanecki, P., Fu, C., Crowley, M.R., Crossman, D.K., Armstrong, L., Babovic-Vuksanovic, D., Bergner, A., Blakeley, J.O., Blumenthal, A.L., Daniels, M.S., Feit, H., Gardner, K., Hurst, S., Kobelka, C., Lee, C., Nagy, R., Rauen, K.A., Slopis, J.M., Suwannarat, P., Westman, J.A., Zanko, A., Korf, B.R., Messiaen, L. M., 2014. Germline Loss-Of-Function Mutations In Lztr1 Predispose To An Inherited Disorder Of Multiple Schwannomas. Nature Genetics, 46(2), Pp. 182-187.

Plotkin, S.R., Albers, A.C., Babovic-Vuksanovic, D., Blakeley, J.O., Breakefield, X.O., Dunn, C.M., Evans, D.G., Fisher, M.J ., Friedman, J.M., Giovannini, M., Gutmann, D.H., Kalamarides, M., Mcclatchey, A.I., Messiaen, L., Morrison, H., Parkinson, D.B., Stemmer-Rachamimov, A.O., Van 
Raamsdonk, C.D., Riccardi, V.M., Rosser, T., Schindeler, A., Smith, M.J., Stevenson, D.A., Ullrich, N.J ., Van Der Vaart, T., Weiss, B., Widemann, B.C., Zhu, Y., Bakker, A.C., Lloyd, A.C., 2014. Update from the 2013 International Neurofibromatosis Conference. American journal of medical genetics.Part A, 164A(12), pp. 2969-2978.

Plotkin, S.R., Blakeley, J.O., Evans, D.G., Hanemann, C.O., Hulsebos, T.J., Hunter-Schaedle, K., Kalpana, G.V., Korf, B., Messiaen, L., Papi, L., Ratner, N., Sherman, L.S., Smith, M.J., StemmerRachamimov, A.O., Vitte, J., Giovannini, M., 2013. Update from the 2011 International Schwannomatosis Workshop: From genetics to diagnostic criteria. American journal of medical genetics.Part A, 161A(3), pp. 405-416.

Smith, M.J., Isidor, B., Beetz, C., Williams, S.G., Bhaskar, S.S., Richer, W., O'sullivan, J., Anderson, B., Daly, S.B., Urquhart, J.E., Fryer, A., Rustad, C.F., Mills, S.J., Samii, A., Du Plessis, D., Halliday, D., Barbarot, S., Bourdeaut, F., Newman, W.G., Evans, D.G., 2015. Mutations in LZTR1 add to the complex heterogeneity of schwannomatosis. Neurology, 84(2), pp. 141-147.

Smith, M.J., Kulkarni, A., Rustad, C., Bowers, N.L., Wallace, A.J., Holder, S.E., Heiberg, A., Ramsden, R.T., Evans, D.G., 2012. Vestibular schwannomas occur in schwannomatosis and should not be considered an exclusion criterion for clinical diagnosis. American journal of medical genetics.Part $A, 158 \mathrm{~A}(1)$, pp. 215-219.

Smith, M.J., Walker, J.A., Shen, Y., Stemmer-Rachamimov, A., Gusella, J.F., Plotkin, S.R., 2012. Expression of SMARCB1 (INI 1) mutations in familial schwannomatosis. Human molecular genetics, 21(24), pp. 5239-5245.

Smith, M.J., Wallace, A.J., Bowers, N.L., Rustad, C.F., Woods, C.G., Leschziner, G.D., Ferner, R.E., Evans, D.G., 2012. Frequency of SMARCB1 mutations in familial and sporadic schwannomatosis. Neurogenetics, 13(2), pp. 141-145.

Wolkenstein, P., Benchikhi, H., Zeller, J., Wechsler, J., Revuz, J., 1997. Schwannomatosis: a clinical entity distinct from neurofibromatosis type 2. Dermatology (Basel, Switzerland), 195(3), pp. 228-231. 


\begin{tabular}{|c|c|c|c|}
\hline 2005 Criteria & $\begin{array}{l}\text { Suggested } \\
\text { Modifications } \\
\text { ("Manchester } \\
\text { Criteria") }\end{array}$ & $\begin{array}{l}\text { Suggested } \\
\text { Modifications }\end{array}$ & 2013 Criteria \\
\hline $\begin{array}{l}\text { (Mac Collin et al, } \\
\text { 2005) }\end{array}$ & (Baser et al, 2006) & $\begin{array}{l}\text { (Plotkin et al, } \\
\text { 2013) }\end{array}$ & $\begin{array}{l}\text { (applied for ISR } \\
\text { enrollment) }\end{array}$ \\
\hline Definite & Definite & & Definite \\
\hline $\begin{array}{l}\text { *Age>30 years AND } \\
\text { two or more non- } \\
\text { intradermal } 1 \text { with } \\
\text { histologic } \\
\text { confirmation AND } \\
\text { no evidence of } \\
\text { vestibular tumor on } \\
\text { high-quality MRI } \\
\text { scan AND no known } \\
\text { constitutional NF2 } \\
\text { mutation OR *One } \\
\text { pathologically } \\
\text { confirmed non- } \\
\text { vestibular } \\
\text { schwannoma plus a } \\
\text { first-degree relative } \\
\text { who meets above } \\
\text { criteria" }\end{array}$ & $\begin{array}{l}\text { *Age older than } 30 \\
\text { years and two or } \\
\text { more non- } \\
\text { intradermal } \\
\text { schwannomas, at } \\
\text { least one with } \\
\text { histologic } \\
\text { confirmation * One } \\
\text { pathologically } \\
\text { confirmed } \\
\text { schwannoma plus a } \\
\text { first-degree relative } \\
\text { who meets the above } \\
\text { criteria }\end{array}$ & $\begin{array}{l}\text { Molecular } \\
\text { Diagnosis * } \\
\text { Two or more } \\
\text { pathologically proved } \\
\text { schwannomas or } \\
\text { meningiomas AND } \\
\text { genetic studies of at } \\
\text { least two tumors } \\
\text { with loss of } \\
\text { heterozygosity (LOH) } \\
\text { for chromosome } 22 \\
\text { and two different } \\
\text { NF2 mutations; if } \\
\text { there is a common } \\
\text { SMARCB1 mutation, } \\
\text { this defines } \\
\text { SMARCB1-associated } \\
\text { schwannomatosis } \\
\text { OR * One } \\
\text { pathologically proved } \\
\text { schwannoma or } \\
\text { meningioma AND } \\
\text { germline SMARCB1 } \\
\text { pathogenic mutation } \\
\text { Clinical } \\
\text { Diagnosis: *Two or } \\
\text { more non- } \\
\text { intradermal } \\
\text { schwannomas, one } \\
\text { with Pathological } \\
\text { confirmation, by } \\
\text { high-quality MRI } \\
\text { (detailed study of } \\
\text { internal auditory } \\
\text { canal with slices no } \\
\text { more than } 3 \text { mm } \\
\text { thick), with no } \\
\text { evidence of bilateral } \\
\text { vestibular }\end{array}$ & $\begin{array}{l}\text { Molecular } \\
\text { Diagnosis } \\
\text { *Molecular } \\
\text { diagnostic testing } \\
\text { consistent with a } \\
\text { diagnosis of } \\
\text { schwannomatosis } \\
\text { (SMARCB1 or LZTR1 } \\
\text { mutation obtained } \\
\text { from blood or tumor } \\
\text { tissue) *No family } \\
\text { history of NF2 in a } \\
\text { first degree relative } \\
\text { Clinical Diagnosis } \\
\text { All of the } \\
\text { following } \\
\text { conditions must } \\
\text { be met:*Two or } \\
\text { more non-vestibular } \\
\text { schwannomas, at } \\
\text { least one proven by } \\
\text { biopsy *Brain MRI } \\
\text { with and without } \\
\text { gadolinium and with } \\
\text { thin cuts ( }{ }^{2} 3 \text { mm) } \\
\text { through the IAC has } \\
\text { been performed and } \\
\text { there is no evidence } \\
\text { of unilateral or } \\
\text { bilateral vestibular } \\
\text { schwannomas. }{ }^{*} \text { If } \\
\text { less than } 20 \text { years old } \\
\text { germline testing for } \\
\text { NF2 has been } \\
\text { performed and is } \\
\text { negative. * If } 40+ \\
\text { years old, unilateral } \\
\text { vestibular } \\
\text { schwannoma is }\end{array}$ \\
\hline
\end{tabular}




\begin{tabular}{|c|c|c|c|}
\hline & & $\begin{array}{l}\text { schwannoma *One } \\
\text { pathologically } \\
\text { confirmed } \\
\text { schwannoma } \\
\text { or intracranial } \\
\text { meningioma AND } \\
\text { affected first-degree } \\
\text { relative }\end{array}$ & acceptable. \\
\hline Possible & Possible & & \\
\hline $\begin{array}{l}\text { *Age <30 years AND } \\
\text { two or more non- } \\
\text { intradermal } \\
\text { schwannomas, at } \\
\text { least } 1 \text { with } \\
\text { histologic } \\
\text { confirmation AND } \\
\text { no evidence of } \\
\text { vestibular tumor on } \\
\text { high quality MRI } \\
\text { scan AND no known } \\
\text { constitutional NF2 } \\
\text { mutation OR *Age } \\
>45 \text { years AND two } \\
\text { or more non- } \\
\text { intradermal } \\
\text { schwannomas, at } \\
\text { least } 1 \text { with } \\
\text { histologic } \\
\text { confirmation AND } \\
\text { no symptoms of } 8 \text { th } \\
\text { nerve dysfunction } \\
\text { AND no known } \\
\text { constitutional NF2 } \\
\text { mutation OR } \\
\text { *Radiographic } \\
\text { evidence of a non- } \\
\text { vestibular } \\
\text { schwannoma and } \\
\text { first degree relative } \\
\text { meeting criteria for } \\
\text { definite } \\
\text { schwannomatosis }\end{array}$ & $\begin{array}{l}\text { *Age younger than } \\
30 \text { years and two or } \\
\text { more non- } \\
\text { intradermal } \\
\text { schwannomas, at } \\
\text { least one with } \\
\text { histologic } \\
\text { confirmation. *Age } \\
\text { older than } 45 \text { years } \\
\text { and two or more } \\
\text { Non-intradermal } \\
\text { schwannomas, at } \\
\text { least one with } \\
\text { histologic } \\
\text { confirmation. } \\
\text { *Radiographic } \\
\text { evidence of a } \\
\text { schwannoma and } \\
\text { first degree relative } \\
\text { meeting the criteria } \\
\text { for definite } \\
\text { schwannomatosis }\end{array}$ & & \\
\hline $\begin{array}{l}\text { Segmental } \\
\text { schwannomatosi } \\
\text { s } \\
\text { Meets criteria for } \\
\text { either definite or }\end{array}$ & $\begin{array}{l}\text { Segmental } \\
\text { schwannomatosis } \\
\text { Meets criteria for } \\
\text { either definite or } \\
\text { possible }\end{array}$ & & \\
\hline
\end{tabular}




\begin{tabular}{|c|c|c|c|}
\hline \multirow{3}{*}{$\begin{array}{l}\text { possible } \\
\text { schwannomatosis } \\
\text { but limited to one } \\
\text { limb or five or fewer } \\
\text { contiguous } \\
\text { segments of the } \\
\text { spine. }\end{array}$} & $\begin{array}{l}\text { schwannomatosis } \\
\text { but limited to one } \\
\text { limb or five or fewer } \\
\text { contiguous segments } \\
\text { of the spine }\end{array}$ & & \\
\hline & $\begin{array}{l}\text { Patients with the } \\
\text { following } \\
\text { characteristics do } \\
\text { not fulfil } \\
\text { diagnosis for } \\
\text { schwannomatosis } \\
\text { : }\end{array}$ & $\begin{array}{l}\text { Patients with the } \\
\text { following } \\
\text { characteristics do } \\
\text { not fulfill } \\
\text { diagnosis for } \\
\text { schwannomatosis } \\
\text { : }\end{array}$ & $\begin{array}{l}\text { Patients with the } \\
\text { following } \\
\text { characteristics do } \\
\text { not fulfill } \\
\text { diagnosis for } \\
\text { schwannomatosis } \\
\text { : }\end{array}$ \\
\hline & $\begin{array}{l}\text { *Germline } \\
\text { pathogenic NF2 } \\
\text { mutation *Fulfill } \\
\text { diagnostic criteria for } \\
\text { NF2*First degree } \\
\text { relative with NF2 }\end{array}$ & $\begin{array}{l}\text { *Germline } \\
\text { pathogenic NF2 } \\
\text { mutation *Fulfill } \\
\text { diagnostic criteria for } \\
\text { NF2*First-degree } \\
\text { relative with } \\
\text { NF2*Schwannomas } \\
\text { in previous field of } \\
\text { radiation therapy } \\
\text { only }\end{array}$ & $\begin{array}{l}\text { *Germline } \\
\text { pathogenic NF2 } \\
\text { mutation *Fulfill } \\
\text { diagnostic criteria for } \\
\text { NF2*First degree } \\
\text { relative with } \\
\text { NF2*Schwannomas } \\
\text { in previous field of } \\
\text { radiation therapy } \\
\text { only }\end{array}$ \\
\hline
\end{tabular}


Table II: Topics of research interest in the field of schwannomatosis GENETICS OF SCHWANNOMATOSIS

*Detection of additional predisposing, or modifying, genes

* Determination of affected cellular pathways

\section{GENOTYPE/PHENOTYPE CORRELATIONS}

*Understand why the mutation patterns in schwannomatosis families are distinct and usually separate from patients with the inherited predisposition to rhabdoid tumors

*Mutations of SMARCB1 in schwannomatosis are found throughout the gene.

Understanding specific roles of each domain of SMARCB1 will provide insight to function

* Determine the downstream pathways affected by SMARCB1

* Determine the function of LZTR1 in schwannomatosis

*Determine the downstream pathways affected by LZTR1

INHERITANCE PATTERNS

*Examine penetrance of germline mutations

\section{PATHOLOGIC DIAGNOSIS OF SCHWANNOMATOSIS ASSOCIATED SCHWANNOMAS}

*Distinguish schwannomatosis-related schwannomas and NF2-related schwannomas

\section{TUMOR BURDEN IN SCHWANNOMATOSIS}

*What is the value of whole body magnetic resonance imaging? What are the limitations?

\section{EFFECTIVENESS OF CURRENT OR NEW TREATMENTS}

*Pain medications

*Radiation

*Chemotherapy

* Surgical outcomes

*Development of novel therapies based on affected pathways

\section{DEVELOPMENT OF TOOLS FOR RESEARCH}

*Creation of patient -derived cell lines for metabolomics/drug efficacy

*Xenograft of patient tissue

* Mouse models for relevant mutation testing

*Analysis of mice carrying both conditional mutant Nf2 and Smarcb1 alleles will be critical to assess how inactivation of Smarcb1/Nf2 influences the development of schwannomatosisassociated phenotype 
Table III: Data points collected in the ISR

Patient demographics

Year of birth

Sex

Approximate age of presentation of first feature

Is this person living?

Age at death?

Was an autopsy done at the time of death?

Presenting feature

Pain

Palpable/Visible Mass

Neurological Deficit

Incidental Finding on Imaging

\section{Genetic Testing}

Has genetic testing been performed on this patient?

Genes Tested

Results

Method of testing

Year tested

Was more than one mutation in SMARCB1/INI1 gene located within this subject?

\section{Family History}

Is there a family history of schwannomatosis?

Have any family members with schwannomatosis had genetic testing?

Is there history of any tumors other than schwannomas?

Type of tumor

Has this tumor been proven by pathology?

\section{Treatment}

Has this person ever had surgery for a schwannoma?

Has this person ever had radiation for a schwannoma?

Has this person ever had radiation for any other reason?

\section{Tumor location}

Has this person had a whole body MRI scan?

Are all features of schwannomatosis currently known in this person limited to one limb?

Are all features of schwannomatosis currently known in this person limited to five or fewer contiguous segments of the spine?

\section{Symptoms and management}

Has this person ever had pain?

Does this person currently have pain?

Is this person seeing a specialist responsible for managing their pain?

Has this person ever had a neurologic deficit?

Does this person currently have a neurologic deficit? 
What type of tissue is available for this person?

Blood

Tissue

Paraffin

Frozen

Has this person ever seen the following specialists (select all that apply below):

ENT

GI

Cardiologist

Pulmonologist

Ophthalmologist

Dermatologist

Orthopedist

Psychiatrist

Plastic Surgeon

Pain Management

Based on the current criteria is this case suspected or confirmed Suspected

Confirmed 
Table IV: Demographics of ISR patient population

Sex

Male

Female

Age at Diagnosis

$<20$

21-30

$31-40$

$41-50$

$51-60$

$60+$

Current Age

$<20$

21-30

31-40

$41-50$

$51-60$

61-70

71-80

80-90

deceased

Presenting feature

Pain and Mass

Pain only

Mass only

Neuro deficit and pain

Pain, mass and neuro deficit

Neuro deficit only

Neuro deficit and mass

incidental finding on imaging

Experienced Pain

Yes

No

Family History of Disease

Yes

No

\section{Treatment Type}

Surgery

Yes

No
$1 \%$

$33 \%$

$74 \%$

$26 \%$

$36 \%$

$64 \%$

$94 \%$

$\%$ of patients

$57 \%$

$43 \%$

$24 \%$

$29 \%$

$21 \%$

$17 \%$

$6 \%$

$3 \%$

$16 \%$

$20 \%$

$28 \%$

$17 \%$

$7 \%$

$2 \%$

$3 \%$

$29 \%$

$17 \%$

$7 \%$

$6 \%$

$4 \%$

$3 \%$

$1 \%$

$6 \%$ 


\section{Radiation}

Yes

No

$2 \%$

Tissue Availability

$98 \%$

Tissue Available

\# of patients

Blood

108

Blood and Tumor

85

Tumor only

38

19 


\section{Table V: Genetic Testing}

Percentage of patients who had genetic testing for germline mutations in SMARCB1, LZTR1, and/or NF2 somatic mutations

Yes

No

Gene

SMARCB1 (germline)

LZTR1 (germline)

NF2 (somatic mutations

in tumor)

131/389 (34\%)

$258 / 389(66 \%)$

Patients tested

123/131 (94\%)

102/131 (78\%)

26/131 (20\%)
Patients positive for mutations

65/123 (53\%)

$57 / 102(56 \%)$

$18 / 26$ (69\%) 